DOI https://doi.org/10.30525/978-9934-26-026-1-16

\title{
TRADE AND ECONOMIC AND CULTURAL RELATIONS OF GALICIAN LAND AND VOLHYNIA WITH WESTERN EUROPEAN COUNTRIES
}

Chuyko O. D.

\section{INTRODUCTION}

Foreign policy, trade and economic relations with neighbors are an important factor influencing cultural and artistic processes in any country. The subject of international relations of the princely period was widely covered in the academic literature, primarily on the basis of written sources ${ }^{1}$. However, the new archaeological material allows us to better clarify several important issues ${ }^{2}$. Archaeological and numismatic finds are the most reliable sources of information about the trade in pre-Mongol Rus. They give a broader picture of medieval economic centers, as well as trade routes. Of course, new artefacts complement the written sources. A comprehensive study of all their types will help to obtain modern general conclusions about economic relations of the Kyiv state with other countries of that time.

Archaeological objects of ancient Ruthenian imports fall into two categories. The first category includes items of mass import (silver coins, glass and stone beads, cheap metal ornaments, weapons, some types of bronze utensils, glazed ceramics). They are most relevant for the study of economic relations. Such items came to Rus mainly in the process of trade. They characterize both foreign economic relations and daily internal exchange, which is an indicator of the level of economic development of Galicia-Volhynia Rus. Foreign goods might have first entered city markets and fairs, from there merchants distributed them to other settlements. Articles of mass import, except for weapons, had a wide market, and their consumers were the feudal nobility, artisans and rural population.

${ }^{1}$ Грицак П. Галицько-Волинська Держава. НТШ. Бібліотека украйнознавства. Ч. 5. Нью-Йорк, 1958 (Галич, 1995); Ждан М. До питання про залежність ГалицькоВолинської Русі від Золотої Орди. Украӥнський історичний журнал. 1967. Ч. 1-2. C. 34-71.

2 Аулих В. Торговля. Археология Прикарпатья, Вольли и Закарпатья (раннесловынский й древнерусский периоды). Киев, 1990. С. 93-96; С. Терський. Волинь в системі міжнародних зв'язків Київської Русі (X-XIV ст.). Наукові записки. Львівський історичний музей. 1995. Вип. 1. С. 73-88; Копитко А. Речі близькосхідного походження на території Галицької і Волинської земель (X-XIII ст.). Археологічні дослідження Львівського університету. 2000. Вип. 4. С. 166-172. 
The second category of archeological sources includes luxury items: handicrafts made of gold, silver and precious stones, silk fabrics. They did not always come to Rus through trade, but were often among trophies of war, ambassadorial and wedding gifts, mostly for the princely and boyar elite, warriors and ministers of the Church.

Adoption of Christianity as the official religion roughly coincided with a new stage in the development of foreign trade in Rus, which began in the eleventh century and was marked by a noticable expansion of the volume and range of goods. The Kyiv metropolitanate needed church books, icons, and other cult objects for worship and religious ceremonies. They were then imported from Byzantium, as their own production had not yet been arranged. Very often church implements, bells (originally imported from the West), books, icons, and expensive crosses came to churches and monasteries as gifts from princes and boyars. However, written sources provide evidence that churches also bought religious items and new imported goods.

Workshops affiliated to large temples or monasteries that specialized mainly in the manufacture of church attributes (crosses, icons, cult implements, icon plating), or bell casting, used other imported metals (gold, silver, copper and tin). In the $11^{\text {th }}-13^{\text {th }}$ centuries, ancient Ruthenian workshops received silver in the form of coins and ingots from Western and Central Europe (England, Germany, Hungary, Czechia and other countries). From there, travelers, soldiers, merchants, immigrants exported some rare articles or highly artistic specimens as personal belongings ${ }^{3}$.

\section{Vectors of trade, economic and cultural relations of the Principality of Galicia-Volhynia with Byzantium and the Asian East}

The trade of Rus with Central European states, as well as with individual Western European countries, was of major importance. Written sources of the early tenth century mention Ruthenian merchants in the cities on the Danube, as well as Prague, Krakow. The Raffelstetten Customs Regulations of 903-904 mention wax, horses and slaves brought to the Middle Danube by the Ruthenians. Abraham ben Jakob (second half of the tenth century) reported that Ruthenians came from Krakow to Prague to trade in various goods and Byzantine gold, along with Ugrians, Jews and Muslims. The former exported slaves, zinc and fur from Prague to their countries. The European type swords found here, originating from the Ulberht and Ingelrii

\footnotetext{
${ }^{3}$ Перхавко В. Древнерусские бронзовые кресты-энколпионы в сопределенных с Русью странах Европы. Церковная археология: материаль Первой Всеросийской конференции. Ч. 2 : Християнство и древнерусская культура. Санкт-Петербург; Псков, 1996. С. 66-69.
} 
bladesmith workshops, evidence on the close ties of Rus-Ukraine with the Rhineland region in the tenth century. Twenty-one specimens of swords from this area were found in the lands of Kyivan Rus. As for the territory of finds, the monuments of European weapons are distributed as follows: Kyiv land, Chernihiv and Dnieper rapids - six specimens in each, two specimens in Pereyaslav, and one specimen in Galicia and Volhynia ${ }^{4}$.

The heyday of Rus' trade with Western European countries reached its peak in the second half of the $11^{\text {th }}-12^{\text {th }}$ centuries. During this period, Rus imported metal, bone and stone artworks, both of religious and secular nature. They brought in Romanesque castings, such as bells, candlesticks, aquamalines in the form of animal and human figures, bowls, boxes, enamel lamps made in Limoges, decorative spoons for communion, as well as handicrafts made from carved bone $\mathrm{s}^{5}$. For example, as mentioned by V. Darkevych ${ }^{6}$, the bells were brought from the West. As can be seen in the picture, they are already in a more perfect shape, hence, producing more pleasant, richer overtones of sound.

The main centers of import were Lorraine (14 artefacts), Saxony (10), Westphalia, Minden (95), Friesland (4). There are six known specimens from France, including four Limoges enamels. Two artefacts come from Scandinavia or Jutland, one each from Tyrol, Hungary and southern Italy. Chronologically, these finds are distributed as follows: $11^{\text {th }}-12^{\text {th }}$ centuries Kyiv and Volhynia (one artefact each); $12^{\text {th }}-13^{\text {th }}$ centuries - Principalities of Kyiv (13), Chernihiv (5), Galicia-Volhynia (3), Pereyaslav (2), Chersonese (1); the first half of the $13^{\text {th }}$ century - Principalities of Kyiv (7), Chernihiv (3), Pereyaslav (2), Galicia and Crimea (1) ${ }^{7}$. Weapons continued to be exported from the Romanesque world.

When considering the ancient Ruthenian exports to Western Europe, it should be noted that in addition to traditional natural raw materials, Rus exported handicrafts, such as encolpion crosses, goods made from Ovruch slate, especially spinning wheels, glazed ceramics, including decorated Easter eggs, tubular cams, helmets. The main highway, which connected the south of Rus with the states of Romanesque Europe, ran from Kyiv through Volhynia and the Carpathians to Krakow and Prague, and from there - to Western European lands.

4 Зоценко В. Торговля в южнорусских землях (VIII - первая половина XIII вв.). Киев, 1986. Т. 3. С. 470-485.

5 Там само.

${ }^{6}$ Даркевич В. Произведсния западного художественного ремесла в Восточной Европе (X-XIV вв.). Москва, 1966. С. 66.

7 Зоценко В. Торговля в южнорусских землях (VIII - первая половина XIII вв.). Киев, 1986. Т. 3. С. 480. 
Early archeological finds attesting to the trade of the Eastern Slavs with Western European countries date back to the tenth century. In particular, in the $10^{\text {th }}$ - first half of the $11^{\text {th }}$ centuries, Rus imported Frankish swords stamped by Middle Rhine masters. Imports of these weapons from the West are characterized by the influx of Western currency - the dinar. Replacing the flow of Eastern dirham coins (since the 1020s), dinars became the main currency in circulation in Eastern Slavic states. About 400 treasures and individual finds with western coins have been recorded in Eastern Europe. Most often, ancient Ruthenian treasures with dinars date back to the last quarter of the tenth century. Their number especially grows in the eleventh century and declines sharply in the twelfth century, when silver was supplied from Germany in the form of round ingots ${ }^{8}$.

The bracteate finds attest to the connections of Volhynia and Galicia with the countries of Western and Central Europe. The Khotyn treasure discovered in 1889 (dating back to 1225-1230), included more than 1,000 coins of this type minted in Thuringia, Upper and Lower Saxony, Hesse, as well as in Carinthia, Hungary and Czechia ${ }^{9}$.

England and Germany, where the metal was mined, were the main exporters of silver coins to Poland, Sweden, the South-Eastern Baltics and Rus. Probably that is why German-made dinars predominate in ancient Ruthenian treasures. Much fewer coins are known from Denmark, Czechia, Hungary, Sweden, Poland, Norway, Italy, and France. Statistics of ancient Ruthenian treasures reveal their monetary affinity with the finds of the southern coast of the Baltic Sea and their difference from the treasures of Scandinavia. It can be deduced that the main flow of dinars to Rus went through the port West Slavic cities: Wolin, Szczecin, Kolobrzeg, Gdansk, of course, bypassing the Scandinavian Peninsula.

According to researchers, the active influx of works of art from the West begins in the second half of the twelfth century. It is this period of time that accounts for the largest group of imported items. The reason for the increased number of imported goods was economic and social changes in Western Europe causing flourishing of urban crafts, which became a lucrative and honorable occupation, gradually moving from monasteries to the hands of secular urban artisans.

8 Потин В. Топография находок западноевропейских монет X-XIII вв. на территории Древней Руси. Труды Государственного Эрмитажа. Ленинград, 1967. T. IX. C. 106-188.

${ }^{9}$ Р. Шуст. Нумізматика. Історія грошового обігу та монетної справи в Україні. Київ, 2007. С. 73. 


\section{Ruthenian-Polish exchanges}

Relations with Poland comprised one of the important areas of international activity in the regions of Kyivan Rus. Initiated in the late tenth century, these political ties had a significant impact on the domestic political development of both countries, as well as on the international situation in Eastern Europe. Numerous archeological finds in their territories attest to active trade and economic contacts, while coordinated efforts were of great importance in the trade processes with Byzantium and eastern countries, thus, contributing to intercultural communication.

Among the sources that cover this aspect, texts of chronicles are of great importance, especially the Tale of Bygone Years, the $13^{\text {th }}$ century Kyiv Illustrated Chronicle known as per the $15^{\text {th }}$ century Radziwill Chronicle, the $13^{\text {th }}$-century Galician-Volhynian Chronicle. The Novgorod, Suzdal, Nikon and other chronicles also contain some information on the history of Ruthenian-Polish relations. Some interesting data can be found in the Kyivan Caves Patericon, Teachings of Volodymyr Monomakh, Tale of the blinding of Prince Vasylko, as well as in the $12^{\text {th }}$ century Polish chronicles of Gall Anonim and Wincenty Kadlubek.

According to the sources, many immigrants from Rus lived in medieval Poland. Although the study of matrimonial ties, alongside with the migration processes caused by them, has long been on the margins of historical and art studies, now it has become significantly more active.

The history of dynastic marriages, especially the bilateral marriages of the Piasts and Ruriks in the pre-Mongol period, is recorded in Polish sources (the chronicles of Gall Anonim and Wincenty Kadlubek, the Wielkopolska (Greater Poland) Chronicle, the late medieval compilation of Jan Dlugosz, and many others). During the $11^{\text {th }}-13^{\text {th }}$ centuries, there was an active interdynastic matrimonial practice, numbering dozens of marriages. Currently, at least sixteen such princely visits to Poland have been recorded, accompanied by Ruthenian courtiers ${ }^{10}$.

Indicative of the twelfth-century Polish-Galician dynastic ties is the marriage of Prince Yaroslav Osmomysl's daughter Vysheslava ( $\dagger$ after 1187) to Prince Mieszko's son Odon I (1141 (1149) - 1194). Most often, Polish-Ruthenian marriages took place in the thirteenth century, and Polish rulers oftentimes married princesses who were born in the Galicia-Volhynia lands. Although the plausibility of some marriages has been the subject of serious scholarly disputes, there is no doubt that the Ruriks' marital

${ }^{10}$ Волощук M. Rutheni in Polonia XI-XIII вв. : кратки очерки проблемы. Rubikids in dynanastic relations: politics, customs, culture, religion $\left(10^{\text {th }}-16^{\text {th }} \mathrm{c}\right.$.). Publication after 4-th International Conference (Mogilno, 14-16 th November, 2013). Krakow, 2014. P. 145. 
relationship with the Piasts has outnumbered the dynastic alliances of the Ruthenian princes with the Hungarian rulers.

Servants and a priest always accompanied Polish rulers' young wives who arrived from Rus. We learn from the Chronicle of Thietmar of Merserburg about a similar entourage of the daughter of Boleslaw the Brave (966/967-1025), sent to Rus as the bride of Prince Sviatopolk Volodymyrovych (c. 975-1019). This marriage is believed to have initiated a number of Polish-Ruthenian matrimonial unions with their own characteristic features ${ }^{11}$.

In the mid twelfth century, at the stage of development of a new powerful political entity in the western part of Rus - the Galician principality, representatives of the Piast dynasty were interested in establishing close ties with princely Halych. In the first year of the reign (1154) of Yaroslav Volodymyrovych (Osmomysl), his daughter Vysheslava married the eldest son of Mieszko Stary, Prince Odon. "It seems that in the middle of the twelfth century not only the House of Monomakh, but also Galician princes Volodymyrko Volodarevych and his son Yaroslav sought an alliance with Polish princes. This brought them first neutrality and then Polish support" ${ }^{\text {, }}$.

Fact-based material shows that in the 1140s-1170s Rus-Poland relations underwent significant changes due to the final transition from relatively centralized relations to relations based on the principles of polycentrism. On the Polish side, Krakow was the main political center to maintain these contacts. However, it then represented only the Małopolska (Lesser Poland) principality. Rus developed ties with the West Slavic neighboring state mainly through Volhynia and Galicia ${ }^{13}$.

In the 1180s, against the background of a certain tendency towards decentralization in the Kyiv state, there was increased political pressure on Volhynia and Galician lands from the Małopolska principality. On the other hand, the influence of the Principality of Volhynia (later Galicia-Volhynia) on political life in Poland was growing since the early 1190s. Frequent infighting in Galicia-Volhynia Rus, which broke out after the death of Prince Roman in 1205, created favorable conditions for intensified Polish military

11 Свердлов М. Известия о Руси в хронике Титмара Мерзербургского. Древнейтие государства на территории СССР. Материалы и исследования. 1975 г. Москва, 1976. С. 109-110; Щавелева Н. Польки - жени руських князей (XI - середина ХІІІ в.). Древнейшие государства на территории СССР. Материаль и исследования. 1987. Москва, 1989. С. 51.

${ }^{12}$ Войтович Л. Галич у політичному житті Європи XI-XIV століть. Львів, 2015. C. 267.

${ }^{13}$ Головко А. Древняя Русь и Польша в политических взаимоотношениях X первой трети ХІІІ вв. Київ, 1988. С. 82. 
and political intervention in the affairs of the East Slavic lands. In general, in the first third of the thirteenth century, political ties between the two neighboring countries were not stable, and short-lived peaceful relations were followed by the expansionist policy of the rulers of Małopolska and attempts to capture the territory of Western Volhynia with its developed cities.

The trade route that connected Kyivan Rus with the German land via the Polish and Czech lands is known from written sources of the early ninth century. There was an important stage in the history of trade in the $9^{\text {th }}-10^{\text {th }}$ centuries, when trade relations between Poland and the Arab East intensified through the mediation of Kyivan Rus, which can be traced back with the help of treasures of Arab coins of the $10^{\text {th }}-11^{\text {th }}$ centuries $^{14}$. Polish-Ruthenian trade relations revived in the second half of the $10^{\text {th }}-11^{\text {th }}$ centuries due to the economic development of both countries.

Written sources rarely mention trade items. Since the economic structures of the two countries are very similar, it may seem that trade between them was not large-scale. However, in Poland there was a great demand for Arab imports, which came here through Rus, while the Arab East needed Slavic products. Landowners were interested in early medieval trade, hoping for profits. Trade organizers were interested in imported fabrics, jewelry, weapons, spices, wine, horses, etc.

Galician salt is believed to be transported from Sandomierz to the north and west, and its volume was to be very large. The product of Galician saltworks was also imported to Polish lands past Sandomierz. For this purpose, the Bug-Vistula highway was used, which ran in the same direction. Trade in Galician salt in Poland lasted from the $11^{\text {th }}$ to the mid $-13^{\text {th }}$ century. Another real value of this food product is known from one of the authors of the Kyivan Caves Patericon: "When Sviatopolk and David discussed Vasylko's blindness, Sviatopolk made him blind, listening to David Igorevych, with Volodar and Vasylko himself, and not letting the guests from Halych or the boats from Przemyśl and there was no salt in the whole Ruthenian land"15.

In addition to salt, Galicia-Volhynia Rus helped its neighbors with grain. During crop failures in the Polish, Lithuanian, and Yotvingian lands, Volodymyr Vasylkovych $(\dagger 1288)$ sent here boats with bread along the Bug River and then along the Narew River ${ }^{16}$.

${ }^{14}$ Alexandrowicz S. Stosunki handlowe polsko-ruskie do roku 1240. Zeczyty aukowe uniwersytetu im. A. Mickiewicza. 1958. Zeszyt 3. S. 21-67.

15 Абрамович Д. Києво-Печерський Патерик. Київ, 1991. С. 151-152.

${ }^{16}$ Лiтопис Руський. С. 286. 
The scale of Ruthenian-Polish trade is well illustrated by the so-called Drohiczyn seals and stamps. The first lead seals in Rus date back to the tenth century. Seals are not a purely Ruthenian invention, they, like lead hanging seals, came to Ukrainian lands from Byzantium. Many different hypotheses are still expressed about their functional purpose. Lead seals are small, double, often round or arbitrary thin plates with a thin lace or thick thread between them. The two halves were joined by compression and had various marks on their surface, mostly different on both sides of the seal. Many of them were found in Drohiczyn. Researchers have collected many such monuments in their collections. Drohiczyn seals are stored in museums in Belarus, Lithuania, Poland and Ukraine.

There were several trade routes between Poland and Kyivan Rus. One of them is the transit trade route via Poland and, of course, via Volhynia, which connected Western Europe with Kyiv, as well as the countries of the East. Merchants used this route from the early $9^{\text {th }}$ century until 1240 . The second route of Polish-Ruthenian trade was the Baltic one. It especially facilitated the trade of Poland with the East during the period of intensive so-called Arab trade, as well as serving for direct relations between Poland and Northern Rus. The shortest route connecting Rus with Poland was via the rivers Pripyat and Bug.

Contacts between the population of Poland and Rus were ancient and regular and had a positive effect on the development of both countries. According to reputable sources, such relations covered the territories bordering the Rurik monarchy. Lively Ruthenian-Polish exchange was supported by immigrants from Rus (migrants, bilateral marriages) living in Poland. Such relationships were built on the principles of polycentrism and facilitated by the established network of ancient trade routes. They transported not only goods from the East, but also local ones, in particular salt from the Galician lands, amber from Volhynia and others. Evidence of intensive trade are Drohiczyn seals, spinning wheels and crosses, products from Kyivan Rus known both in Silesia and in Greater Poland.

\section{Trade, economic and cultural ties of the Principality of Galicia-Volhynia with the German lands}

While the intensity of ties of Galician Rus with Poland and Hungary in the $12^{\text {th }}-13^{\text {th }}$ centuries is reported almost annually in the Hypatian Codex and other sources, there is much less historical information about such contacts with German lands. Of course, the most lively relations took place in the Danube regions of Germany. Sources allow us to draw certain conclusions about economic ties (the late twelfth-century charters of the Styrian and Austrian dukes mention Ruthenian merchants and trade with their country) ${ }^{17}$.

17 Пашуто В. Очерки по истории Галицко-Волынской Руси. Москва, 1950. C. 171 . 
Sources suggest close contacts between the Galician princely family and individual church centers in Germany. It is known that Roman Mstyslavych donated to the monastery of St. Peter in Erfurt. After the death of Emperor Henry VI (September 28, 1197), there were two contenders for the royal and imperial crowns among German princes. In this confrontation, Prince Roman supported Philip of Swabia (Staufen dynasty).

Roman Mstyslavych's direct contacts with King Philip of Swabia and his allies are evidenced by the history of visits of the Galician prince to Erfurt. The synod of the monastery of St. Peter, located in this Thuringian city, mentions the "King of Rus" Roman. He made a generous donation to this monastery, and for this, he was among the people commemorated annually during the funeral service on the day of their death: "The thirteenth calends of July. Roman, King of Rus, he gave us thirty marks" ${ }^{18}$. As it was proved, this record can be attributed only to the GaliciaVolhynia prince Roman Mstyslavych, because "the thirteenth calends of July", is the day in 1205 when the Ruthenian ruler died in the battle with the Poles near Zawichost ${ }^{19}$.

Prince Roman's generous donation to a distant Catholic monastery, as 30 marks were then equated to about seven kilograms of silver, is explained by the need to strengthen trade ties between the western territories of Kyivan Rus and East Germany. At the same time, this gesture of the Galician ruler is interpreted as affinity for the Catholic Church ${ }^{20}$.

There are also versions of Prince Roman's personal ties to the monastery in Erfurt. It is probable that as a child the future ruler was brought up for some time in the local monastery ${ }^{21}$.

Note that donations to foreign monasteries were not exceptional gestures of Ruthenian princes. It is known that Volodymyr Monomakh donated to the monastery of St. Jacob in Regensburg, and Princess Gytha had close contacts with the monastery of St. Panteleimon in Cologne. Princely donations to foreign monasteries were common practice in the Principality of Galicia-Volhynia. The papal bulls of 1216 and 1218 mention among the list of revenues of the Hungarian monastery of St. Dmytro on Sava (Savasendemeter) in Sremska Mitrovica as receiving an annual income in

18 Майоров О. Галицько-Волинський князь Роман Мстиславич. Володар, воїн, дипломат. Біла Церква, 2011. Т. 1. С. 132.

${ }^{19}$ Назаренко А. Западноевропейские источники. Древняя Русь в свете зарубежнblx источников. Москва, 1999. С. 263-264.

20 Чубатий М. Західна Україна і Рим у XIII столітті у своїх змагання до церковної унії. Записки НТШ. Львів, 1917. Т. 123-124. С. 9.

${ }^{21}$ Головко О. Князь Роман Мстиславич та його доба. Нарис з історії політичного життя Південної Русі ХІІ - початку ХІІІ століття. Київ, 2001. С. 187. 
the form of 13 centars of wax (weighing about $700 \mathrm{~kg}$ ) from some "Ruthenian kings from Galicia"22.

The fact that Prince Roman donated to the monastery in Erfurt shows that Galician diplomacy was well acquainted with the cultural processes of Europe at that time. During the reign of the mentioned Galician-Volhynia ruler, the Benedictine monastery of St. Apostles Peter and Paul played a significant role in the political life not only of Thuringia but also of the whole Germany. Founded in the $11^{\text {th }}$ century, it was one of the richest and most privileged monasteries.

The Chronicle of Alberic, which describes the events of world history from, according to the chronicler, the "creation of the world" to the $1240 \mathrm{~s}$, is important in the coverage of Galician-German contacts in the early thirteenth century. According to the French source (Chronicles of Alberic), Roman's campaign in Poland in 1205 was allegedly meant to Saxony ${ }^{23}$.

Princes of Galicia and Volhynia maintained allied relations with the Staufen dynasty for a long time. According to the Act of Frederick Barbarossa, in 1165, during negotiations with the Hungarians in Vienna, King Vladislav of Bohemia recommended to the emperor an unknown Ruthenian ruler, contemptuously called a "Ruthenian prince". Scholars suggest that the vassal of the German emperor could be the Galician prince Yaroslav Osmomysl. His son Volodymyr took refuge at the court of Barbarossa in 1189 (a descendant of the Galician prince then just escaped from Hungarian captivity) ${ }^{24}$. Roman Mstyslavych had family ties with the Staufens. Roman's grandfather Izyaslav Mstyslavych (1097-1154) was married to one of the representatives of this family. There is even a version that Roman was a direct relative of Philip of Swabia, because they could have been married to the daughters of the Byzantine Emperor Isaac II Angel Anna and Irina.

It is noteworthy that there was a German gate in ancient Halych, which could mark an important direction of Galician international trade ${ }^{25}$. In addition, numerous archeological finds attest to active trade relations of Galicia-Volhynia Rus with German lands ${ }^{26}$. Probable German influences on Galician architecture were noticed by Ya. Pasternak. In particular, he noted the origins of the masons who took part in the construction of the

22 Майоров О. Галицько-Волинський князь Роман Мстиславич. Володар, воїн, дипломат. Біла Церква, 2011. Т. 1. С. 121.

${ }^{23}$ Там само. С. 144.

24 Літопис Руський. С. 349.

${ }^{25}$ Там само. С. 393.

${ }^{26}$ Даркевич В. Произведения западного художественного ремесла в Востточной Европе X-XIV векав. Москва, 1966. 
Assumption Cathedral in Halych and gave it the features of the Romanesque style ${ }^{27}$.

Among the convincing arguments is the example of the use of a rolling frieze over the windows in the construction of the portal of the building of the Cathedral of Ancient Halych. Analogies are found in the architecture of Germany and France, in particular, in the Cathedral of Bremen, built during the reign of Henry IV (1056-1106), the early twelfth-century monastery church in Milsztat (main portal), monasteries in Basel of the second half of the twelfth century, cathedrals in Worms $\left(12^{\text {th }}-13^{\text {th }}\right.$ centuries $)$, cathedrals in Bamberg $\left(12^{\text {th }}-13^{\text {th }}\right.$ centuries). According to Ya. Pasternak, another detail of the Assumption Cathedral having exact analogies in German architecture is a jagged frieze, which is observed in the church of St. Jacob in Regensburg (second half of the twelfth century), the church of St. Michael in Altenstadt (late twelfth century), the Cathedral of Saints Peter and George in Bamberg (late twelfth century), the Cistercian monastery of Lehnin in Prussia (1180-1262), the St. Peter's Cathedral in Worms $\left(12^{\text {th }}-13^{\text {th }}\right.$ centuries $)$, the temple of Ellwangen $\left(12^{\text {th }}-13^{\text {th }}\right.$ centuries $)$. In addition, the lion stone mask on one of the columns on the apses of the Assumption Cathedral has an analogy in the northern French cathedral in Bayeux ${ }^{28}$.

The interior of the Assumption Cathedral has a white stone relief with a carved winged serpent. V. Vuytsyk found interesting analogies to this element of facade decor, which probably adorned the western portal. $\mathrm{He}$ names them among the architectural monuments of the German medieval lands: the reliefs of the western facade of the church of St. Jacob in Regensburg (the twelfth century), a carved dragon emitting a flame in the form of a palm branch on the capital of the cathedral in Gurka (the twelfthcentury Austria), the tympanum reliefs of the temples of Saxony and Thuringia ${ }^{29}$.

Goods from Western Europe, where the centers of arts and crafts were concentrated, were also transported by water to southern Germany, to the upper reaches of the Danube (their route ran along the Rhine through the rivers Meuse, Main and Neckar). The city of Regensburg played a significant role in trade relations between East and West. In the twelfth century, it had a corporation of merchants who traded with Rus via the Danube and Czechia.

${ }^{27}$ Пастернак Я. Старий Галич. Археологічно-історичні досліди у 1850-1943 pp. Івано-Франківськ, 1998.

${ }^{28}$ Там само.

29 Вуйцик В. Нова пам'ятка давньоруської білокам'яної різьби. Вісник Інституту Укрзахідпроектреставрачія. Львів, 2004. Ч. 14. С. 281-282. 


\section{The system of trade, economic and cultural relations of Galicia and Volhynia with Czechia}

The issue of Czech-Ruthenian trade relations, as a part of the western direction of Kyiv's foreign trade activity, is somewhat leveled off, with an attempt to shed light only on economic relations. This is primarily due to the lack of reliable sources. Trade relations between Kyivan Rus and Czechia and Moravia developed from the tenth century onwards in the line of political (dynastic) and cultural ties. The words of the Tale of Bygone Years dated 996 are well-known: "And he travelled with the princes around him in peace - with Boleslaw of Poland, and with Stephen of Hungary, and with Ondronick of Bohemia, and there was peace among them and friendship" 30 . This record reflects the specific good-neighborly relations of Volodymyr with the Prince of Czechia Oldrich (975-1034), based on the ancient traditions of Czech-Ruthenian relations.

In this sense, we should recall the fact of consolidating the power of the Kyivan prince in 981 over the "Cherven Cities", Przemyśl and the whole territory east of the upper Vistula. Volodymyr then approached the borders of the Kyivan state's possessions close to the upper reaches of the Vistula, where, as is well known, the possessions of the Prague House of Premyslids ended at that time, and thus the borders of the Czech state stretched. It was under the conditions of rapprochement between it and the western territories of Kyivan Rus that enabled the appearance of two Czechs among the wives of the Kyivan prince. Later, in the $11^{\text {th }}-12^{\text {th }}$ centuries, marriages between members of the Ruthenian Princely House and the House of Premyslids were not uncommon either.

They are confirmed by the assumption that the daughter of Izyaslav Yaroslavovych married a Moravian prince in 1075. In 1132, Prince Vratislav of Brno married a Ruthenian princess, who may have been the daughter of Prince Vasylko of Terebovlya. In 1143, the Novgorod prince Sviatopolk Mstyslavych married one of the Moravian princesses, a close relative of Prince Otto III, who found refuge in Rus in 1126, when he was hiding from his hostile prince Sobieslaw of Bohemia ${ }^{31}$.

Dynastic ties made the political basis of international cooperation, which involved the prince's entourage: boyars, the army, etc. The ancient Czech (legendary) genealogical tradition often mentions the connection between the Czech nobility and the Ruthenian princely entourage. According to some versions, its roots can be traced back to the House of Ryzimberk and often Zierotin. In the $11^{\text {th }}-12^{\text {th }}$ centuries, Czech soldiers participated in Ruthenian

\footnotetext{
30 Літопис руський. С. 71.

31 Флоровський А. Чешско-русские торговые отношения X-XII вв. Международнье связи России до XVII в. : сборник ст. Москва, 1961. С. 67.
} 
inter-princely disputes and conflicts. Chroniclers mention presence of such soldiers in Volhynia, Kyiv and other parts of Rus.

In the field of cultural communication, Kyivan Rus was close to Czechia and Moravia due to common ethnic features of their population, as well as the fact that in the $10^{\text {th }}-12^{\text {th }}$ centuries these countries belonged to the Slavonic tradition of Church worship and writing. It is well known that this tradition has its roots in the ancient Great Moravian, Cyril and Methodius cultural framework. An important fact is that it is on Ruthenian soil that Czech monuments (mostly of a hagiographic nature) have been preserved in the Slavonic Church written heritage, as well as those translated from Latin. The names of the Czech saints, Prince Wenceslas and Princess Ludmila, were adapted to the Ruthenian language culture, and the Czech church environment already introduced the cult of the first Ruthenian saints Borys and Hlib.

Another important element of money circulation in Central and Northern Europe in the $10^{\text {th }}-11^{\text {th }}$ centuries was Czech silver. However, it did not come into Rus via Prague - Krakow - Przemyśl - Kyiv, but through the Baltics, and then from the Gulf of Finland to the northern and northwestern regions of Eastern Europe.

Recently, a lot of archeological material has been discovered, which attests to the active movement of merchants in the direction of Prague-Kyiv via Krakow and Przemyśl. Finds of Arab dirhams were discovered in Prague, Moravia and in Kelc, which was a stopping point of the trade route from Moravia to the north, towards Krakow. Treasures of dirhams from the territory of Poland are known in the east-west direction - they were discovered near Lublin, Przemyśl and on the San River. It is possible that even then, in the $10^{\text {th }}-12^{\text {th }}$ centuries, the trade route passed through Lublin to the Odra, to Wroclaw, which played a very important role in Czechia's trade relations with Poland and neighboring countries to the east.

The finds of silver Arab coins are considered a strong argument that denies the subjective opinions of Polish (R. Jakymovych) and Czech scholars that there was only the northern link between Eastern and Central Europe on the trade route, through the cities of Kyiv, Krakow, Opole, Kladzko to Czechia, while the road through Przemyśl actually connected Western Europe with the ancient Ruthenian East.

Numismatic and archaeological data on the northern direction of Czech trade suggest that Czechia supported trade with Northern Rus through Greater Poland (where there are more Arab finds than in Lesser Poland), and further along the Bug (Drohiczyn) ${ }^{32}$, via Minsk - Grodno to Pskov and Veliky Novgorod.

We find later evidence of Czech trade with the Ruthenians on the Lower Danube in Prince Ivan Rostislavych Berladnyk's document of 1134. It is

${ }^{32}$ Lewicki T. Znaczenie handniowieczu i zagadkowe plomby olowiane znalezione w tej miescowosii. Kwartalnik histori kultury materialnej. 1956. T. IV. № 2. S. 289-297. 
very important for us that the charter mentions the lower Danube, the city of Barlad and small Halych (Galati) where goods were brought from Czechia (the charter determines the procedure for paying duty for them).

It is very difficult to establish the ways of Czech goods being transported to the Lower Danube. Most likely, they went through Hungary, and then via the main highway through Krakow and Przemyśl, from where there could have lead branched roads to present-day Bukovina, Transcarpathian Ukraine, as archaeologists have discovered a number of finds in the form of Arab coins in Przemyśl, through the southern slopes of Carpathians to Halych, Kolomyia and Khust in Transcarpathia.

It is quite possible that it was in this direction that Czechia's trade with Byzantium developed, with its epicenter on the Lower Danube. In this case, the Czech-Ruthenian trade relations of the $10^{\text {th }}-12^{\text {th }}$ centuries are rightly considered in the broader perspective of international economic relations, as the Prague - Krakow - Przemyśl - Kyiv route is gaining transit value in the contacts of Kyivan Rus with distant East Asian countries, with Jewish-Arab trade mediation becoming a significant indicator in this sense.

It is noteworthy that the Ruthenian market was also connected with Central European centers via another route, namely through Hungary. This direction turned aside from the mentioned main highway in the vicinity of Halych and further joined the system of roads leading from the Middle Danube, probably from Esztergom to the west via Slovakia (Bratislava, Nitra), Moravia and Czechia or via Austria and Bavaria to Regensburg.

$11^{\text {th }}-13^{\text {th }}$ century source evidence about the way merchants traveled to Regensburg via Hungary resonates with later documentary data, with the well-known Esztergom tariff of 1288, which mentions Czech and Polish merchants "who came from Rus".

Archaeological materials concerning the Ruthenian-Czech exchange support literary and numismatic data of the $10^{\text {th }}-12^{\text {th }}$ centuries. Rus exported to the West forest products in large quantities, such as honey, wax, fur, and leather. In addition, live goods - slaves - were supplied to the Central European market, in particular the Prague market, in the tenth and subsequent centuries. These were people of different ethnic backgrounds. Prague was then an important center of the slave trade. No wonder, it was then called Canaan in Jewish circles, that is, a country where slaves are traded $^{33}$. The slave trade was in the hands of Jewish merchants, as reflected in the relief at the Gniezno gate, where the Bishop of Prague, Adalbert (Wojciech) (955-997), freed slaves from the hands of such merchants.

${ }^{33}$ Lewicki T. Osadnictwo slowianskie i niewolniey slowiansky w Krajach musulmanskich wedlug sredniowiecznych pisarzy arabskich. Przeglad historyczny. Warszawa, 1952. T. 43. Z. 3-4. S. 485. 


\section{Relations between Rus and the Danube states}

Although irregularly, written sources cover trading history along the Danube. These sources include the Raffelstetten Customs Regulations of 903-904, the records of the so-called Bavarian Geographer (last quarter of the ninth century), the records of the Hispano-Arabic traveler Abraham ben Jakub, who visited the West Slavic lands in 965-966.

The Danube has always been an important transportation artery not only for peoples living in coastal areas. In the $9^{\text {th }}-13^{\text {th }}$ centuries, Kyivan Rus, as well as its western lands supported various contacts (political, economic, cultural) with all the regions of the Danube. In the Middle Ages, German, Jewish, Bulgarian, Italian and in particular ancient Ruthenian merchants conducted lively trade in many Danube centers.

Merchants often used another southern road to travel from GaliciaVolhynia Rus to the Upper Danube. This route went through the mountainous Carpathian passes (Veretsky, etc.), Transcarpathia, and Hungary. One of the articles of the $13^{\text {th }}$ century Esztergom Customs Regulations, which came down to us as of 1288 , but dates back to 1198, states: "A merchant coming from Rus with one horse, can enter Pest or Esztergom, or another place, and, like those who carry expensive furs, pays half a mark" ${ }^{34}$. Further, the document mentions customs duties paid by merchants coming to Esztergom from the Balkan lands, Czechia, Italy, Vienna. It is no coincidence that Ruthenian merchants were the first to be mentioned, as this reflects the activity and importance of Hungarian-Ruthenian economic ties.

Located on the right bank of the Danube on the border with Slovakia, the famous trading center Esztergom was the capital of Hungary and the residence of Hungarian kings from the late tenth to mid-thirteenth century. It connected Southern Rus with Vienna and Regensburg, so merchants traveling from the East Slavic lands or back often visited it. Expensive furs, wine, slaves, fabrics, copper, lead, salt, fish, and wax were transported through the Esztergom customs ${ }^{35}$. Back in the tenth century, the ancient Ruthenians appreciated the Hungarian horses, which are mentioned not only in the chronicles, but also in The Tale of Igor's Campaign. Silver was also transported from Hungary to Rus, often in the form of local minted items ${ }^{36}$.

Oral tradition brought forward an attempt of Prince Sviatoslav to explain the reason and transfer of the residence from Kyiv, given the commercial

${ }^{34}$ Новосельцев А., Пашуто В. Внешняя торговля Древней Руси (до средины ХІІІ в.). История СССР. 1967. № 2. С. 86.

35 Перхавко В. Торговий мир средневековой Руси. Москва, 2006. С. 125.

36 Потин В. Древняя Русь и европейские государства в X-XIII вв. Лениград, 1968. C. 86. 
and economic importance of Pereyaslavets on the Danube, under which we read Pereyaslav the Great - a significant trading center of the $10^{\text {th }}$-century Bulgaria.

Archaeological and numismatic sources confirm that silver in the form of Hungarian and Czech dinar coins was imported to Kyivan Rus, but not to the Lower Danube. For example, an $11^{\text {th }}$ century chronicler the trade and economic characteristics of Pereyaslavets on the Danube (ie Pereyaslav the Great, and in a broader sense - the entire Lower Danube of the second half of the tenth century by contemporary evidence of Rus's trade relations ${ }^{37}$.

Merchants' travels from Rus to Byzantium (including its lower Danube possessions) continued in the $11^{\text {th }}$ century, after the failure of Sviatoslav's attempt to gain a foothold in the Balkans in 967-971. With the fall of the First Bulgarian Kingdom and the establishment of Byzantine rule in its territory, its borders, and hence its markets came much closer to the lands of the Eastern Slavs. Now their ships ascended the Danube more often, entering Pereyaslavets (Little Preslav), Noviodunum (Isaceea), Doroston (Sinistra), which became powerful economic and trading centers in the $11^{\text {th }}-12^{\text {th }}$ centuries. People, who regularly went to trade with the Greeks, are called "Greekans" in Kyiv chroniclers. On their way, they were ambushed by dangers, mostly attacks by pirates and nomads. Princely infighting also led to considerable losses in trade.

In the twelfth century, there is already direct evidence from written sources about Rus's trade with the Danube provinces of Byzantium. The most valuable of these is, without a doubt, the work of the Arab geographer Muhammad al-Idrisi (1100-1165) A Diversion for the Man Longing to Travel to Far-Off Places (Tabula Rogeriana), written around 1154. It provides interesting information about the connections with Rus of the Bulgarian city of Shumen (Masiunus), located south of the Danube: "Masiunus is a crowded city. It houses one office in Rus. This is a prosperous city. It has numerous markets and an abundance of natural resources" ${ }^{\prime 38}$. Several handicrafts of the $11^{\text {th }}-12^{\text {th }}$ centuries brought from Rus were found in Shumen. It is obvious that the emergence and functioning there of an ancient Ruthenian trade "court" ("council") in the $11^{\text {th }}-12^{\text {th }}$ centuries is associated with its role as an intermediary center, through which East Slavic goods were transported from the lower Danube cities into the heart of Bulgaria by land, starting from Doroston (Sinistra) ${ }^{39}$.

\footnotetext{
${ }^{37}$ Коновалова Н., Перхавко В. Древняя Русь и Нижнее Подунавья. Москва, 2000. C. 53-69.

${ }^{38}$ Перхавко В. О торговых контактах Киева с Болгарией в IX-XII вв. Проблемы социально-экономической истории феодальной России. Москва, 1984. С. 95-96.

${ }^{39}$ Так само. С. 95.
} 
From the mid- $12^{\text {th }}$ century, Halych, which challenged Kyiv in terms of foreign trade, played the most active role in the Lower Danube. Galician merchants reached the lower Danube centers both by rivers (primarily the Dniester and the Prut) or over the Black Sea, and by land, along which goods made by ancient Ruthenian artisans (spinning wheels made from Ovruch slate, tubular door cams, bronze encolpion crosses) are found in the territory of present-day Moldova, especially in the cities of Batca-Doamnei, Hlincea, Dorosti, Kendesti, Piatra, Neamt, Spinoasa $)^{40}$.

Among the main sources for the study of Ruthenian-Hungarian relations, two chronicles are of special interest: one was created in the late twelfth century by Master Peter, notary of King Bela IV (1206-1270), the other is Vienna illustrated chronicle, compiled in 1358 by monk Mark Calti, the court chaplain of King Louis (1326-1382). Information from Hungarian sources supplement Ruthenian chronicles, statements of the Byzantine Emperor Constantine VII the Crimson (905-959) and oriental travelers and geographers. There is some evidence in Western chronicles as well. However, the most important now are the results of archaeological research, which helps to restore the history of neighboring contacts of Kyivan Rus.

The Galician dynasty of the Rostyslav had family ties with the Hungarian royal court, so its army was sometimes involved in military conflicts. Hungarian troops approached Halych twice: in 1188-1189 and in 1215-1219. Both times, it was associated with difficult periods in the history of the Rostyslav dynasty, in the first case the power passed into the hands of the illegitimate son of Yaroslav Osmomysl (1188), and in the second - into the hands of the Volhynia dynasty (1215).

According to chronicles, Hungary supplied silver and horses to the countries to the east of it. However, while mentioning silver and horses coming to Pereyaslavets on the Danube from the Czechs and the Ugrians, as well as fur and wax and servants from Rus, the chronicle does not mention direct trade relations between Hungary and Rus ${ }^{41}$.

Important events in the history of Galician-Hungarian-Byzantine relations took place in the 1150s-1160s. Then the wars between Hungary and Byzantium became more frequent. After the traditional route through the Black Sea, which connected Western Europe, the territory of Rus and the northern seas, was blocked by the Polovtsians in the southern Ruthenian steppes in the mid-twelfth century, the main transit highway for trade with the West shifted to the Danube (the Regensburg Way). A large part of it ran along the Dniester to the territory controlled by the Principality of Galicia. Of course, this situation helped to improve its trade.

\footnotetext{
${ }^{40}$ Spinei V. Moldova in secolele XI-XIV. Bucharest, 1982. P. 126-128. Fig 17-21.

41 Літопис руський. С. 39.
} 
Hungary played a significant role in the historical and cultural processes taking place in the $11^{\text {th }}-13^{\text {th }}$ century ancient Ruthenian state, but the most effective Ugro-Ruthenian relations can be traced in the border areas - in Galician Rus, as well as in the lands of the Dniester Lowland and the lower reaches of the Danube, which were under its control. In the era of the Second Crusade and the Byzantine-Hungarian wars in the twelfth century, these areas were of particular importance in all-Ruthenian foreign policy, because they were part of the system of ancient Ruthenian-Byzantine and Byzantine-European relations.

Relative tolerance of the Ruthenian Church to the Catholic faith in Hungary was an important factor in strengthening Galician-Hungarian ties. They became even stronger when Hungary was twice forced to accept the spiritual supremacy of Constantinople in the second half of the twelfth century, which in the eyes of Galicians made its neighbor a de facto Orthodox country.

\section{CONCLUSIONS}

The latest achievements of archeology, ethnography, history, linguistics, art history and other sciences, supplemented by evidence from ancient written sources, helped us to elaborate on the idea of material and spiritual culture of the Principality of Galicia-Volhynia. Its art appears as a complex and multifaceted phenomenon, whose development was significantly ensured by close association with the heritage of the Kyiv state, as well as multifaceted relations with all close and distant neighbors. The geographical location of Galicia-Volhynia Rus, its natural and climatic conditions favorable for trade, development of its craft and trade centers facilitated this process. Merchants from different countries took part in transit trade and establishment of trade carried on along ancient local and transit land, river and sea routes.

The study of the relations of the Principality of Galicia-Volhynia with Central and Western European countries attests to its long-term stay in the cultural space of the European Middle Ages. Based on the studies of the development of interethnic contacts of Galicia-Volhynia Rus, as well as analysis of contemporary material monument, we were able to specify the broad geography of their origin and distribution, to outline the first approximation of regional differences in style, iconography, tradition, the level of adaptation of outside cultural influences. Inter-dynastic marriages strengthened constant relationships. They were a guarantee of the need for relations, ensured their strength and duration.

The establishment of relations with Rome was an important sphere of international activity of the Galicia-Volhynia state. They were especially intensified by the discussion of possible agreements on joint action against 
the Mongol-Tatar invasion, the events surrounding the coronation of Danylo Halytsky.

Another key to the development of the art of Volhynia and the Galician lands was close cultural ties with those countries whose ethnic and cultural composition of the population was especially close, in particular due to the conditions of Christianization. Mutual penetration of cultures was facilitated by the center of Christianity common for many ethnic groups, namely Constantinople.

The military factor played an important role in cultural and artistic borrowings. When it was necessary to protect their possessions or their expansion intentions, rulers established allied relations with each other. They were one of the factors influencing rapid exchange of military achievements, in particular in the field of martial art skills, new military equipment of that time or its decoration. At the same time, it was also an important stimulus for the development of handicrafts, expansion of the circle of craftsmen, who made various types of weapons and engaged in their decoration.

The study of monuments discovered in archeological complexes, which included objects made by craftsmen from the western territories of Kyivan Rus, shows that such goods were imported due to political, dynastic, cultural, trade and church-religious ties, as well as migration of the East Slavic population. At the same time, the works of masters of other states are often found in the Principality of Galicia-Volhynia.

Galicia-Volhynia Rus often gave shelter not only to former rulers of different countries, but also to their relatives, whose life circumstances forced them to become exiles. Pilgrims facilitated the exchange of artistic monuments between the states thus, leading to strengthening canons of monastic life in the Galicia-Volhynia area, developing the network of monastic complexes and, as a result, promotion of religious and philosophical thought, mutual penetration of modern trends in architecture, painting, handicrafts, copying books and their promotion.

\section{SUMMARY}

The study of foreign policy and trade and economic relations of GaliciaVolhynia lands with its neighbors showed the importance of such international relations, revealed their stimulating role in the field of cultural and artistic processes. Revealing places of origin of imported goods helped to determine the countries with which the Principality of Galicia-Volhynia conducted trade, as well as intermediary states located on the main routes of trade. Dating of the imported objects discovered by archaeologists allowed outlining certain periods of their imports.

Relations with Poland were long-standing and systemic. Relations of the Principality of Galicia-Volhynia with Central and Western European 
countries were stable. The key to establishing close contacts at that time was ethnic and cultural composition of the population, as well as conditions of Christianization. The military factor played certain role in mutual borrowings. The study of the relations of the Principality of GaliciaVolhynia with other states attests to its long-term stay in the cultural area of the European Middle Ages. This ensured close interethnic contacts of the Galicia-Volhynia state, a wide geography of importing and distributing material monuments, development of regional differences in style, iconography, tradition, the level of adaptation of local cultural influences.

Political, dynastic, cultural, trade and church-religious ties, migration, pilgrimage contributed to the exchange of artistic monuments, penetration of religious and philosophical thought to various segments of the population, borrowing modern trends in architecture, painting, handicrafts, making musical instruments, in particular casting of bells, copying books and their promotion.

\section{REFERENCES}

1. Абрамович Д. Києво-Печерський Патерик. Київ : Час, 1991. 280 с.

2. Аулих В.В. Торговля. Археология Прикарпатья, Вольни и Закарпатья (раннесловынский ци древнерусский периоды). Киев : Наукова думка, 1990. С. 93-96.

3. Войтович Л. Галич у політичному житті Європи XI-XIV століть. Львів : Ін-т українознавства імені І. Крип'якевича НАН України, 2015. 475 с.: іл.

4. Волощук M. Rutheni in Polonia XI-XIII вв. : кратки очерки проблемы. Rubikids in dynanastic relations : politics, customs, culture, religion $\left(10^{\text {th }}-16^{\text {th }} c\right.$. $)$. Publication after 4-th International Conference, Mogilno, 14-16 th November, 2013. Krakow, 2014. P. 143-153.

5. Вуйцик В. Нова пам'ятка давньоруської білокам'яної різьби. Укрзахідпроектреставрація : вісник Інституту. 2004. Ч. 14. С. 279-282.

6. Головко А.Б. Древняя Русь и Польша в политических взаимоотношениях X - первой трети XIII вв. Київ : Наукова думка, 1988. $136 \mathrm{c}$.

7. Головко О.Б. Князь Роман Мстиславич та його доба. Нарис 3 історії політичного життя Південної Русі XII - початку XIII століття. Київ : Стилос, 2001. 249 с.

8. Грицак П. Галицько-Волинська Держава. Записки НТШ. Бібліотека українознавства. Ч. 5. Нью-Йорк, 1958 (Галич, 1995). 176 с.

9. Даркевич В.П. Произведения западного художественного ремесла в Восточной Европе (X-XIV вв.). Свод археологических источников. E1-57. Москва : Наука, 1966. 148 с. 
10. Ждан М.Б. До питання про залежність Галицько-Волинської Русі від Золотої Орди. Український історичний журнал. 1967. Ч. 1-2. C. 34-71.

11. Зоценко В.Н. Торговля в южнорусских землях (VIII - первая половина XIII вв.). Археология Украинской ССР. Киев : Наукова думка, 1986. T. 3. С. 470-485.

12. Коновалова Н.Г., Перхавко В.Б. Древняя Русь и Нижнее Подунавья. Москва : Памятники исторической мысли, 2000. 272 с.

13. Копитко А. Речі близькосхідного походження на території Галицької і Волинської земель (X-XIII ст.). Археологічні дослідження Львівського університету. Львів, 2000. Вип. 4. С. 166-172.

14. Літопис руський / пер. 3 давньорус. Л. Махновець. Київ : Дніпро, 1989. $591 \mathrm{c.}$

15. Майоров О. Галицько-волинський князь Роман Мстиславич. Володар, воїн, дипломат. Біла Церква : Вид. О. В. Пшонківський, 2011. $318 \mathrm{c}$.

16. Назаренко А.В. Западноевропейские источники. Древняя Русь в свете зарубежных источников. Москва : Логос, 1999. С. 259-407.

17. Новосельцев А.П., Пашуто В.Т. Внешняя торговля Древней Руси (до средины ХІІІ в.). История СССР. 1967. № 3. С. 81-108.

18. Пастернак Я. Старий Галич : археологічно-історичні досліди у 1850-1943 р. Івано-Франківськ : Плай, 1998. 347 с.

19. Пашуто В.Т. Очерки по истории Галицко-Волынской Руси. Москва : Изд-во АН СССР, 1950. 333 с.

20. Перхавко В.Б. Древнерусские бронзовые кресты-энколпионы в сопределенных с Русью странах Европы. Церковная археология : материалы Первой Всеросийской конференции. Ч. 2 : Християнство и древнерусская культура. Санкт-Петербург ; Псков, 1996. С. 66-69.

21. Перхавко В.Б. О торговых контактах Киева с Болгарией в IX-XII вв. Проблемы социально-экономической истории феодальной России. Москва : Наука, 1984. С. 92-99.

22. Перхавко В.Б. Торговый мир средневековей Руси. Москва : Академия, 2006. 608 с.: ил.

23. Потин В.М. Древняя Русь и европейские государства в X-XIII вв. Лениград : Советский художник, 1968. 240 с.

24. Потин В.М. Топография находок западноевропейских монет X-XIII вв. на территории Древней Руси. Труды Государственного Эрмитажа. Ленинград : Советский художник, 1967. Т. IX. С. 106-188.

25. Свердлов М. Известия о Руси в хронике Титмара Мерзербургского. Древнейшие государства на территории СССР. Материаль и исследования. 1975 год. Москва : Наука, 1976. C. $102-112$. 
26. Терський С. В. Волинь в системі міжнародних зв'язків Київської Русі (X-XIV ст.). Львівський історичний музей : наукові записки. 1995. Вип. 1. С. 73-88.

27. Флоровський А. В. Чешско-русские торговые отношения X-XII вв. Международные связи России до XVII в. : сборник статей. Москва : Изд-во АН СССР, 1961. С. 64-83.

28. Чубатий М. Західна Україна і Рим у XIII столітті у своїх змагання до церковної унії. Записки НТШ. Львів, 1917. Т. 123-124. C. 1-72.

29. Шуст Р.М. Нумізматика. Історія грошового обігу та монетної справи в Україні : навчальний посібник. Київ : Знання, 2007. 372 с.

30. Щавелева Н. Польки - жены руських князей (XI - середина XIII в.). Древнейшие государства на территории СССР. Материалы и исследования. 1987 год. Москва : Наука, 1989. С. 50-58.

31. Alexandrowicz S. Stosunki handlowe polsko-ruskie do roku 1240. Zeczyty aukowe uniwersytetu im. A. Mickiewicza. 1958. Zeszyt 3. S. 21-67.

32. Lewicki T. Osadnictwo słowiańskie i niewolnicy słowiańscy w krajach muzułmańskich według średniowiecznych pisarzy arabskich. Przeglad historyczny. Warszawa, 1952. T. 43. Z. 3-4. S. 473-491.

33. Lewicki $\mathrm{T}$. Znaczenie handlowe Drohiczyna nad Bugiem we wczesnym średniowieczu i zagadkowe plomby ołowiane znalezione w tej miejscowości. Kwartalnik Historii Kultury Materialnej. Warszawa, 1956. R. IV. № 2. S. 289-297.

34. Spinei V. Moldova în secolele XI-XIV. Edit. Ştiințifică şi Enciclopedică. București, 1982. 383 p.

\section{Information about the author: Chuyko O. D.,}

Doctor of Arts Studies, Associate Professor, Associate Professor at the Department of Design and Theory of Art Vasyl Stefanyk Precarpathian National University 57, Shevchenko str., Ivano-Frankivsk, 76018, Ukraine 